\title{
The incidence, the most common symptoms and risk factors of altitude sickness in children
}

\author{
Rozpowszechnienie, najczęstsze objawy i czynniki ryzyka choroby wysokogórskiej u dzieci
}

\begin{abstract}
High-altitude tourism is gaining popularity. Mountains are also becoming an increasingly popular destination for school or family trips. This suggests that the number of children with high-altitude diseases, including acute mountain sickness (AMS), will also rise. The aim of this literature review was to determine the epidemiology of acute mountain sickness, its most common manifestations and risk factors in children. We analysed papers from the last 5 years, which were found by two independent authors using PubMed, ResearchGate and Google Scholar. The following keywords were used to identify relevant studies: acute mountain sickness, altitude sickness, children (by Medical Subject Headings). After screening with the exclusion criteria, the final analysis included 5 papers, which were assessed for the quality of evidence. The incidence of acute mountain sickness in children is $30-45 \%$ at elevations below $4,000 \mathrm{~m}$. There were no differences compared to an adult population. Headache, sleep disorders and dizziness are the most common symptoms of acute mountain sickness in children. Further research is needed to identify factors that predispose children to this disease. In the light of the increasingly intensive alpine tourism among children, research on the sequelae of acute mountain sickness is recommended.
\end{abstract}

Keywords: paediatrics, acute mountain sickness, altitude sickness

Turystyka dotycząca obszarów położonych na dużych wysokościach staje się coraz bardziej popularna. Góry zaczynają stanowić również coraz częstszy cel wycieczek szkolnych czy rodzinnych. Sugeruje to, że wzrastać będzie liczba dzieci zapadających na choroby charakterystyczne dla środowiska wysokogórskiego, w tym ostrą chorobę wysokogórską. Celem niniejszego przeglądu literatury było określenie epidemiologii tego schorzenia, jego najczęstszych objawów i czynników ryzyka u dzieci. Materiał do niniejszego przeglądu literatury stanowiły prace z ostatnich 5 lat znalezione przez dwóch niezależnych autorów przy użyciu baz publikacji PubMed, ResearchGate oraz Google Scholar. Do identyfikacji odpowiednich badań użyto kombinacji słów kluczowych: acute mountain sickness, altitude sickness, children (według Medical Subject Headings). Ostatecznie, po zastosowaniu kryteriów wyłączających, do analizy włączono 5 prac, które zostały ocenione pod względem wartości dowodów. Częstość występowania ostrej choroby wysokogórskiej u dzieci na wysokości poniżej 4000 m n.p.m. zawiera się w przedziale 30-45\%. Nie obserwuje się różnic w odniesieniu do populacji osób dorosłych. Najczęstszymi objawami ostrej choroby wysokogórskiej u dzieci są bóle głowy, zaburzenia snu oraz zawroty głowy. Określenie czynników predysponujących do zachorowania na tę chorobę u dzieci wymaga dalszych badań. Ze względu na coraz intensywniejszą turystykę wysokogórską wśród dzieci zaleca się prowadzenie badań nad następstwami związanymi z przebytą ostrą chorobą wysokogórską.

Słowa kluczowe: pediatria, ostra choroba wysokogórska, choroba wysokościowa 


\section{INTRODUCTION}

$\mathrm{H}$ igh-altitude tourism is gaining popularity ${ }^{(1)}$. Easier access to modern equipment and training techniques have made high-mountain areas accessible not only to the sports elite, but also to the average person ${ }^{(2)}$. Mountains are also becoming an increasingly popular destination for school and family trips ${ }^{(3)}$. Globally, several hundred thousand children travel with their families to high mountain areas for recreational or professional purposes ${ }^{(4)}$. Therefore, it can be expected that the number of children with high-altitude-related conditions will increase. This should prompt research on the high-altitude physiology to better understand risk factors and the course of diseases such as acute mountain sickness (AMS), high-altitude cerebral oedema (HACE) or high-altitude pulmonary oedema (HAPE).

Acute mountain sickness is defined as a group of nervous and respiratory symptoms, which may occur at high altitudes $^{(5)}$, usually above $2,500 \mathrm{~m}$; however, they may develop already at more than $1,500 \mathrm{~m}$ in susceptible individuals ${ }^{(6)}$. Acute mountain sickness may lead to life-threatening conditions, such as HACE or $\mathrm{HAPE}^{(7)}$. Typical symptoms of AMS include headache, nausea, fatigue, dyspnoea, insomnia, sleep disorders and dizziness ${ }^{(8)}$. More severe forms of AMS may cause difficulty walking, progressive cough, confusion and dyspnoea ${ }^{(5)}$. Factors contributing to the development of AMS include gender, smoking, obesity, physical fitness level, hypocapnia tolerance, ascent rate, individual susceptibility, previous episode of AMS, sleep quality and age $\mathrm{e}^{(8,9)}$. However, the results of studies assessing the influence of age on the development of AMS are not ambiguous $^{(8)}$. The aim of this literature review was to determine the epidemiology, the most common symptoms and risk factors of AMS in children.

\section{MATERIALS AND METHODS}

We analysed papers from the last 5 years (2014-2019), which were found by two independent authors using PubMed, ResearchGate and Google Scholar. The following keywords were used to identify relevant studies: acute mountain sickness, altitude sickness, children (by Medical Subject Headings, MeSH).

The exclusion criteria were as follows: studies older than 5 years, no Polish or English language version of the article, literature reviews, case reports, conference summaries. The literature review consisted of 3 stages. In the first stage, the titles found were reviewed using keywords. The second stage involved an analysis of the abstracts based on the exclusion criteria. In the third stage, full-text analysis of the articles was performed. A total of 5 articles were included in the final analysis (Tab. 1).

We assessed the articles based on the criteria presented in Tab. 2. The criteria were developed based on the Cochrane
Updated September 2006; PRISMA 2009 Checklist; Advice on how to write a systematic review, JM Wardlaw, 14 January 2010 and a quality assessment tool (QUADAS) recommended by the Cochrane Collaboration. Each question was rated on a 2-point scale (0-2), and the scores for all questions were summed up for each article. The results are summarised in Tab. 3.

\section{RESULTS}

Our literature review revealed low quality of evidence (a score of 5) for Chan et al. ${ }^{(10)}$, moderate quality of evidence for Cheng et al. ${ }^{(11)}$, Kriemler et al. (2014) $)^{(14)}$ and Kriemler et al. $(2016)^{(12)}$ (a score of 9, 8 and 9, respectively), as well as high quality of evidence (a score of 10) for Wu et al. ${ }^{(13)}$. The highest and the lowest incidence rates for AMS were reported by Chen et al. (59\%) ${ }^{(10)}$ and Kriemler et al. (2014) (30\%) $)^{(14)}$, respectively. A comparable incidence of AMS among children was reported by Wu et al. $(44.7 \%)^{(13)}$ and Cheng et al. $(40.6 \%)^{(11)}$. Headache, sleep disorders and dizziness were the most common symptoms of AMS. It was suggested by Cheng et al. ${ }^{(11)}$ and $\mathrm{Wu}$ et al. ${ }^{(13)}$ that male gender and increased body mass index (BMI) were risk factors for AMS, which is in contrast with Chan et al. ${ }^{(10)}$. Their study showed that an upper respiratory tract infection developed 7 days prior to a high-altitude trip was a predictive factor for AMS (Tab. 4).

\section{DISCUSSION}

More that 35 million people travel annually to places at altitudes $>3,000 \mathrm{~m}$. Along with the growing popularity of mountain and high-altitude tourism, younger individuals are more likely to get involved in high-altitude sports ${ }^{(15)}$. It is estimated that annually about 5 million people $<18$ years of age practice climbing in the USA alone ${ }^{(16)}$. Staying at high altitudes is associated with specific diseases and their consequences. Papers with moderate [Cheng et al. $(2017)^{(11)}$, Kriemler et al. $(2014)^{(14)}$, Kriemler et al. $\left.(2016)^{(12)}\right]$ and high quality of evidence (Wu et al. ${ }^{(13)}$ ) reported $30-45 \%$ incidence of AMS. Altitudes $>4,000 \mathrm{~m}$ were not reported in any of the discussed publications. Mairer et al., who conducted their study in adult participants, suggested that $34.9 \%$ of subjects developed AMS at an altitude of 3,454 $\mathrm{m}^{(17)}$. This prevalence corresponds with that reported in the cited works. In their study with a moderate quality of evidence, Kriemler et al. (2016) ${ }^{(12)}$ reported no differences between adult and paediatric patients. Gonggalanzi et al. found that $36.7 \%$ of high-altitude travellers developed AMS, and that it was not dependent on their country of origin. This study was conducted in adults ${ }^{(7)}$. In their study in 1,066 participants, Wang et al. showed AMS prevalence of 36\%. Both of these studies correspond with the discussed papers ${ }^{(18)}$. In our review, higher AMS prevalence rates were observed by Chan et al. $(59 \%)^{(10)}$; however, the quality of evidence was low. This may explain the discrepancies between the 


\begin{tabular}{|c|c|c|}
\hline Author, year & Title & Aim, materials and methods \\
\hline Chan et al., 2016 & $\begin{array}{l}\text { Incidence and risk factors associated with acute } \\
\text { mountain sickness in children trekking on Jade } \\
\text { Mountain, Taiwan }\end{array}$ & $\begin{array}{l}\text { Aim: to determine the incidence, risk factors and symptoms of AMS in children trekking } \\
\text { on Jade Mountain, Taiwan } \\
\text { Materials and methods: study group: } 96 \text { healthy non-acclimatised children aged } \\
11-12 \text { years who trekked at an altitude of 2,600-3,952 m for } 3 \text { days; the Lake Louise } \\
\text { Scoring System (LLSS) score was used to assess AMS }{ }^{(10)}\end{array}$ \\
\hline Cheng et al., 2017 & $\begin{array}{l}\text { Incidence and severity of acute mountain sickness } \\
\text { and associated symptoms in children trekking on Xue } \\
\text { Mountain, Taiwan }\end{array}$ & $\begin{array}{l}\text { Aim: to assess the incidence and severity of AMS and associated symptoms in children } \\
\text { Materials and methods: } 197 \text { healthy, non-acclimatized 11- and 12-year-old children } \\
\text { trekking to the summit of Xue Mountain, Taiwan (2,179-3,886 m above sea level) over } \\
3 \text { days; the Lake Louise Scoring System (LLSS) score was used to assess AMS (111) }\end{array}$ \\
\hline \multirow{2}{*}{ Kriemler et al., 2016} & \multirow{2}{*}{$\begin{array}{l}\text { Short-term cardiorespiratory adaptation to high altitude } \\
\text { in children compared with adults }\end{array}$} & $\begin{array}{l}\text { Aim: to verify whether cardiovascular response to acute hypoxia differs between } \\
\text { children and adults, as well as whether respiratory acclimation is associated with aerobic } \\
\text { capacity or AMS }\end{array}$ \\
\hline & & $\begin{array}{l}\text { Materials and methods: } 20 \text { father-child pairs (children } 9 \pm 12 \text { years old) were tested } \\
\text { at } 450 \mathrm{~m} \text { and } 3,450 \mathrm{~m} \text { over } 3 \text { days of ascent; the Lake Louise Scoring System (LLSS) score } \\
\text { was used to assess AMS } \text { (12) }^{-12}\end{array}$ \\
\hline \multirow[b]{2}{*}{ Wu et al., 2015} & \multirow{2}{*}{$\begin{array}{l}\text { The impact of physical fitness and body mass index } \\
\text { in children on the development of acute mountain } \\
\text { sickness: a prospective observational study }\end{array}$} & $\begin{array}{l}\text { Aim: to investigate whether the occurrence of AMS is related to differences in individual } \\
\text { physical fitness and BMl in subjects } 11-13 \text { years of age }\end{array}$ \\
\hline & & $\begin{array}{l}\text { Materials and methods: study group: } 179 \text { children aged } 11-13 \text { years were examined } \\
\text { while trekking from } 25 \mathrm{~m} \text { to } 3,886 \mathrm{~m} \text { over } 3 \text { days and } 2 \text { nights; the Lake Louise Scoring } \\
\text { System (LLSS) score was used to assess AMS }\end{array}$ \\
\hline Kriemler et al., 2014 & $\begin{array}{l}\text { Prevalence of acute mountain sickness at } 3500 \mathrm{~m} \text { within } \\
\text { and between families: a prospective cohort study }\end{array}$ & $\begin{array}{l}\text { Aim: to investigate symptoms, prevalence and associated factors of AMS in families } \\
\text { upon a fast ascent to } 3,450 \mathrm{~m} \\
\text { Materials and methods: study group: } 87 \text { children, } 70 \text { adolescents ( } 312 \text { in total), } \\
\text { and } 155 \text { parents ( } n=312) \text { were assessed for AMS after fast passive ascent by Lake } \\
\text { Louise Scoring System (LLSS) }{ }^{(14)}\end{array}$ \\
\hline \multicolumn{3}{|c|}{ BMI - body mass index. } \\
\hline
\end{tabular}

Tab. 1. Publications qualified for the review (authors, year, title, aim, materials and methods)

\begin{tabular}{|l|l|l|}
\hline \multicolumn{2}{|c|}{ Questions } & \multicolumn{1}{c|}{ Scores } \\
\hline Q1 & Sample size & $\begin{array}{l}0-9-0 \\
10-99-1 \\
\geq 100-2\end{array}$ \\
\hline Q2 & Exclusion criteria & $\begin{array}{l}\text { No }-0 \\
\text { Yes }-2\end{array}$ \\
\hline Q3 & Inclusion criteria & $\begin{array}{l}\text { No }-0 \\
\text { Yes }-2\end{array}$ \\
\hline Q4 & AMS assessment & $\begin{array}{l}\text { No data }-0 \\
\text { Lake Louise Scoring System/medical } \\
\text { examination }-2\end{array}$ \\
\hline Q5 & Local Ethics Committee approval & $\begin{array}{l}\text { No data }-0 \\
\text { Yes }-2\end{array}$ \\
\hline & \multicolumn{2}{|l}{$\begin{array}{l}\text { Yes }-0 \\
\text { No data }-1 \\
\text { No }-2\end{array}$} \\
\hline $\begin{array}{l}\text { Conflict of interest } \\
\text { Scoring system: } \\
00-6-\text { low quality of evidence } \\
\bullet 7-9-\text { moderate quality of evidence } \\
\bullet 10-12-\text { high quality of evidence }\end{array}$ \\
\hline
\end{tabular}

Tab. 2. Assessment criteria and scoring system

results obtained by Mairer et al. ${ }^{(17)}$ and Gonggalanzi et al. ${ }^{(7)}$ and Wang et al. ${ }^{(18)}$. In his literature review, Zieliński observed that $50 \%$ of individuals develop AMS symptoms at an altitude of 3,600-4,300 $\mathrm{m}^{(2)}$. Low quality of evidence and lack of data on AMS severity may account for the results obtained by Chan et al. ${ }^{(10)}$.

Cheng et al. ${ }^{(11)}$ and $\mathrm{Wu}$ et al. ${ }^{(13)}$ suggest that male gender and elevated BMI are risk factors for AMS. The studies were assessed as having moderate and high quality of evidence,

\begin{tabular}{|l|l|c|c|c|c|c|c|c|}
\hline Author & \multicolumn{1}{|c|}{ Title } & \multicolumn{5}{c|}{ Score } & Total \\
\hline & \multicolumn{1}{|c|}{} & 1 & 2 & 3 & 4 & 5 & 6 & \\
\hline $\begin{array}{l}\text { Chan } \\
\text { et al. }\end{array}$ & $\begin{array}{l}\text { Incidence and risk factors } \\
\text { associated with acute } \\
\text { mountain sickness in } \\
\text { children trekking on Jade } \\
\text { Mountain, Taiwan }\end{array}$ & 1 & 0 & 0 & 2 & 0 & 2 & 5 \\
\hline $\begin{array}{l}\text { Cheng } \\
\text { et al. }\end{array}$ & $\begin{array}{l}\text { Incidence and severity of } \\
\text { acute mountain sickness } \\
\text { and associated symptoms } \\
\text { in children trekking on } \\
\text { Xue Mountain, Taiwan }\end{array}$ & 2 & 2 & 0 & 2 & 2 & 1 & 9 \\
\hline $\begin{array}{l}\text { Kriemler } \\
\text { et al. } \\
\text { (2016) }\end{array}$ & $\begin{array}{l}\text { Short-term } \\
\text { cardiorespiratory } \\
\text { adaptation to high } \\
\text { altitude in children } \\
\text { compared with adults }\end{array}$ & 1 & 2 & 0 & 2 & 2 & 1 & 8 \\
\hline Wu et al. & $\begin{array}{l}\text { The impact of physical } \\
\text { fitness and body mass } \\
\text { index in children on the } \\
\text { development of acute } \\
\text { mountain sickness: } \\
\text { a prospective } \\
\text { observational study }\end{array}$ & 2 & 2 & 0 & 2 & 2 & 2 & 10 \\
\hline $\begin{array}{l}\text { Kriemler } \\
\text { et al. } \\
\text { (2014) }\end{array}$ & $\begin{array}{l}\text { Prevalence of acute } \\
\text { mountain sickness } \\
\text { at 3,500 m within and } \\
\text { between families: } \\
\text { a prospective cohort study }\end{array}$ & 1 & 2 & 0 & 2 & 2 & 2 & 9 \\
\hline
\end{tabular}

Tab. 3. Assessment of publications qualified for the review

respectively. In their study with low quality of evidence, Chan et al. ${ }^{(10)}$ showed no sex-related differences. Wang et al. ${ }^{(18)}$ and Horiuchi et al. ${ }^{(19)}$ also found no difference in the incidence of AMS between males and females, which 


\begin{tabular}{|c|c|}
\hline Authors & Summary of results \\
\hline Chan et al., 2016 & $\begin{array}{l}\text { Acute mountain sickness was reported in } 59 \% \text { of children trekking on Jade Mountain over a } 3 \text { day period. Acute mountain } \\
\text { sickness incidence increased significantly with increasing altitude. The most common AMS symptom was headache, followed } \\
\text { by fatigue or weakness, difficulty sleeping, dizziness and gastrointestinal symptoms. Children who had experienced upper } \\
\text { respiratory tract infection within the } 7 \text { days before their trek had a greater risk for AMS. Acute mountain sickness incidence } \\
\text { did not significantly differ depending on gender, recent acute gastroenteritis, menstruation or BMI }{ }^{(10)} \text {. }\end{array}$ \\
\hline Cheng et al., 2017 & $\begin{array}{l}\text { The incidence of AMS was } 40.6 \% \text {, which was higher in males and in individuals with a higher BMI. The prevalence of AMS } \\
\text { over subsequent days was as follows: } 5.6 \% \text { on day } 1,29.4 \% \text { on day } 2 \text {, and } 23.4 \% \text { on day } 3 \text {. The mean LLS of all subjects } \\
\text { was } 1.77 \pm 2.08 \text {. The incidence of severe AMS (LLS } \geq 5) \text { was } 12.5 \% \text {. The mean LLS for the AMS group ( } 3.02 \pm 2.46 \text { ) was } \\
\text { significantly higher than that of the non-AMS group }(0.92 \pm 1.16, p<0.001) \text {. In the AMS group, the mean LLS was } \\
1.00 \pm 1.55 \text { on day } 1,4.09 \pm 1.97 \text { on day } 2 \text {, and } 3.98 \pm 2.42 \text { on day } 3 \text {. Sleep disorders followed by dizziness, and headache } \\
\text { were the most common symptoms. The prevalence of headache was } 46.2 \% \text { on day } 2 \text { at } 3,100 \mathrm{~m} \text {, and } 31.3 \% \text { on day } 3 \\
\text { at the same altitude after climbing the summit }(3,886 \mathrm{~m}) \text {. Boys experienced significantly more headache and fatigue than } \\
\text { girls }(p<0.05) \text {. The LLS scores were significantly higher in the AMS vs. the non-AMS group }(p<0.05) \text { (11). }\end{array}$ \\
\hline Kriemler et al., 2016 & The severity of AMS was mild-to-severe without any intergenerational differences ${ }^{(12)}$. \\
\hline Wu et al., 2015 & $\begin{array}{l}\text { A total of } 44.7 \% \text { of subjects were diagnosed with AMS. Male gender }(p=0.004) \text { and increased BMI }(p<0.001) \text { were risk } \\
\text { factors for AMS. The physical fitness index was comparable in subjects with and without AMS } S^{(13)} \text {. }\end{array}$ \\
\hline Kriemler et al., 2014 & $\begin{array}{l}\text { AMS prevalence was significantly lower in children (21\%) compared to adolescents (34\%) and adults (39\%) on day } 1 \\
(p<0.05) \text {, but not on day } 2(18 \% \text { vs. } 19 \% \text { and } 25 \%) \text {. Cumulative prevalence of AMS was } 30,37 \text {, and } 45 \% \text { in children, } \\
\text { adolescents, and adults, respectively }(p<0.001) \text {. Familial clustering of AMS was consistent and explained } 25-50 \% \text { of AMS } \\
\text { variability }{ }^{(14)} \text {. }\end{array}$ \\
\hline
\end{tabular}

Tab. 4. Summary of results of publications qualified for the review

corresponds with the findings presented by Chan et al. Lawrence and $\operatorname{Reid}^{(20)}$, MacInnis et al. ${ }^{(21)}$, and Venturino ${ }^{(22)}$ showed that females are more susceptible to AMS. This is in contrast with our findings. However, the cited studies ${ }^{(18-22)}$ were conducted among adults rather than children and adolescents, as in the case of Cheng et al. ${ }^{(11)}$, Wu et al. ${ }^{(23)}$ and Chan et al. ${ }^{(10)}$ Hypothetically, these differences may be related to the process of maturation in children. The possible influence of sex hormones on the development of AMS was pointed out by Venturino ${ }^{(22)}$ and Ding et al. ${ }^{(24)}$. The observed differences may indicate further research directions to understand AMS.

Our literature review showed that headache, sleep disorders and dizziness were the most common symptoms of $\mathrm{AMS}^{(10-14)}$. This is in line with a literature review by Zieliński, who reported headache, gastric symptoms, lack of appetite and dizziness as typical symptoms ${ }^{(2)}$. Kępińska and Bajda reported headache, nausea, lack of appetite, vomiting, fainting, dizziness and difficulty falling asleep, weakness and exertional dyspnoea as typical AMS symptoms ${ }^{(25)}$. Both works confirm the most common manifestations observed in children, which were reported in the reviewed articles.

The presented literature lacks data on the possible neurological sequelae of AMS. Among all organs, the brain has the highest basic oxygen demand; therefore, AMS symptoms are largely neurological in nature (effects on the central nervous system - CNS). Generalised hypoxia can affect many body functions, and CNS symptoms are neither specific nor localising ${ }^{(2,26)}$. Cognitive dysfunction may occur when trekking at high altitudes and as a consequence of developing $\operatorname{AMS}^{(27,28)}$. The discussed dysfunctions may be permanent or transient ${ }^{(2)}$. It has been suggested that cultural practices related to raising children at high altitudes may be associated with cognitive deficiencies ${ }^{(28)}$. However, data on the consequences of AMS in children is missing. Due to the intensely developing alpine tourism for children, future studies should focus on this aspect.

\section{CONCLUSIONS}

1. The incidence of AMS among children is $30-45 \%$ for an altitude of 4,000 m. No differences are observed compared to the adult population.

2. Headache, sleep disorders and dizziness are the most common symptoms of AMS in children.

3. Further studies are needed to identify factors predisposing to AMS in children.

4. The increasingly developing alpine tourism for children should encourage research on the consequences of AMS.

\section{Conflict of interest}

Authors do not report any financial or personal connections with other persons or organisations, which might negatively affect the contents of this publication and/or claim authorship rights to this publication.

\section{References}

1. Hjuler KF, Bay B: [Mountain medicine - an introduction. I]. Ugeskr Laeger 2016; 178: V05160367.

2. Zieliński G: [The analysis of the reasons and consequences impact of the high altitude on the human brain]. Medicina Sportiva Practica 2017; 18: 54-57.

3. Pollard AJ, Niermeyer S, Barry P et al.: Children at high altitude: an international consensus statement by an ad hoc committee of the International Society for Mountain Medicine, March 12, 2001. High Alt Med Biol 2001; 2: 389-403.

4. Hackett PH, Roach RC: High-altitude illness. N Engl J Med 2001; 345: 107-114.

5. Simancas-Racines D, Arevalo-Rodriguez I, Osorio D et al.: Interventions for treating acute high altitude illness. Cochrane Database Syst Rev 2018; 6: CD009567. 
6. Brundrett G: Sickness at high altitude: a literature review. J R Soc Promot Health 2002; 122: 14-20.

7. Gonggalanzi, Labasangzhu, Nafstad P et al.: Acute mountain sickness among tourists visiting the high-altitude city of Lhasa at $3658 \mathrm{~m}$ above sea level: a cross-sectional study. Arch Public Health 2016; 74: 23.

8. Wu Y, Zhang $\mathrm{C}$, Chen $\mathrm{Y}$ et al.: Association between acute mountain sickness (AMS) and age: a meta-analysis. Mil Med Res 2018; 5: 14.

9. Harrison MF, Anderson PJ, Johnson JB et al.: Acute mountain sickness symptom severity at the south pole: the influence of selfselected prophylaxis with acetazolamide. PLoS One 2016; 11: e0148206.

10. Chan CW, Lin YC, Chiu YH et al.: Incidence and risk factors associated with acute mountain sickness in children trekking on Jade Mountain, Taiwan. J Travel Med 2016; 23: tav008.

11. Cheng FY, Jeng MJ, Lin YC et al.: Incidence and severity of acute mountain sickness and associated symptoms in children trekking on Xue Mountain, Taiwan. PLoS One 2017; 12: e0183207.

12. Kriemler S, Radtke T, Bürgi F et al.: Short-term cardiorespiratory adaptation to high altitude in children compared with adults. Scand J Med Sci Sports 2016; 26: 147-155.

13. Wu SH, Lin YC, Weng YM et al.: The impact of physical fitness and body mass index in children on the development of acute mountain sickness: a prospective observational study. BMC Pediatr 2015; 15: 55.

14. Kriemler S, Bürgi F, Wick C et al.: Prevalence of acute mountain sickness at $3500 \mathrm{~m}$ within and between families: a prospective cohort study. High Alt Med Biol 2014; 15: 28-38.

15. Smedley T, Grocott MP: Acute high-altitude illness: a clinically orientated review. Br J Pain 2013; 7: 85-94.

16. Siegel SR, Fryer SM: Rock climbing for promoting physical activity in youth. Am J Lifestyle Med 2015; 11: 243-251.

17. Mairer K, Wille M, Burtscher M: The prevalence of and risk factors for acute mountain sickness in the Eastern and Western Alps. High Alt Med Biol 2010; 11: 343-348.
18. Wang SH, Chen YC, Kao WF et al.: Epidemiology of acute mountain sickness on Jade Mountain, Taiwan: an annual prospective observational study. High Alt Med Biol 2010; 11: 43-49.

19. Horiuchi M, Endo J, Akatsuka $S$ et al.: Prevalence of acute mountain sickness on Mount Fuji: a pilot study. J Travel Med 2016; 23: taw024.

20. Lawrence JS, Reid SA: Risk determinants of acute mountain sickness and summit success on a 6-day ascent of Mount Kilimanjaro (5895 m). Wilderness Environ Med 2016; 27: 78-84.

21. MacInnis MJ, Carter EA, Freeman MG et al.: A prospective epidemiological study of acute mountain sickness in Nepalese pilgrims ascending to high altitude (4380 m). PLoS One 2013; 8: e75644.

22. Venturino M: Sex and incidence of acute mountain sickness. Undergraduate Honors Theses [Internet]. 1 January 2015. Available from: https://scholar.colorado.edu/honr_theses/958.

23. Wu JY, Zhang C, Xu YP et al.: Acupuncture therapy in the management of the clinical outcomes for temporomandibular disorders: a PRISMA-compliant meta-analysis. Medicine (Baltimore) 2017; 96: e6064.

24. Ding XH, Wang Y, Cui B et al.: Acute mountain sickness is associated with a high ratio of endogenous testosterone to estradiol after high-altitude exposure at $3,700 \mathrm{~m}$ in young Chinese men. Front Physiol 2019; 9: 1949.

25. Kępińska M, Bajda M: Niebezpieczeństwa związane z przebywaniem na dużej wysokości - ostra choroba wysokogórska. Farm Pol 2010; 66: 13-88.

26. Prince TS, Thurman J, Huebner K: Acute mountain sickness. In: StatPearls [Internet]. StatPearls Publishing, Treasure Island (FL) 2020. Available from: http://www.ncbi.nlm.nih.gov/books/ NBK430716/.

27. Wagner PD: Operation Everest II. High Alt Med Biol 2010; 11: 111-119.

28. Davis JE, Wagner DR, Garvin $\mathrm{N}$ et al.: Cognitive and psychomotor responses to high-altitude exposure in sea level and high-altitude residents of Ecuador. J Physiol Anthropol 2015; 34: 2. 